\title{
Albanian Building Stock Typology and Energy Building Code in Progress towards National Calculation Methodology of Performance on Heating and Cooling.
}

Gjergji Simaku

$\mathrm{PhD}$ Candidate

\begin{abstract}
The expertise on building stock typology used openly available data from the Albanian statistical office. As the CENSUS was not especially designed for gathering data for the energetic evaluation of the building stock, some data were not available on the required level of detail. Estimations were necessary to extrapolate data to the existing stock. Technically, the study selected and described twenty representative categories of residential buildings typology for Albania. Were identified the level and the structure of final energy consumption at present and in the future by building age category, building type, climate zone, and energy end-use. Using an original template excel data sheet, were conducted the calculations of their thermal energy performance in three climate zones, designed standardized retrofit packages, calculated possible energy savings, and investment required by building type. The engineering principle of the Regulation in force, regarding to the legislative act of Energy Building Code in Albania, is beyond any doubt correct and carefully studied. The act is a rule book or the Regulation (energy building code - here The Code) which contains information that is sufficient to perform calculations of the different insulating layers for new construction after the year 2003. Also, the Regulation's algorithms are still relevant in terms of calculation to provide Energy for heating demands in Albania. After 12 years, the Code remains the same and could provide either an optimal potential energy savings to the existing buildings, or an optimal cost-effective of building's insulation without imposing a burden of high financial housing builders to multifamily prospective buyers. Based today Europe's developments on Energy Performance of Buildings, the study is found relevant to provide a methodology for calculation of the energy performance in buildings $\left(\mathrm{kWh} / \mathrm{m}^{2} \mathrm{a}\right)$ based on volumetric coefficient heat losses $\left(\mathrm{G}_{\mathrm{vt}}\right)$ for heating only, the existing indicator of the existing Code. The following study deals with the possibility of transposing the methodology used to the Code into an energy Performance based on minimum requirement for a new Regulation and/or EP Calculation Methodology based on efficient use of energy for heating and cooling purposes.
\end{abstract}

Keywords: energy; buildings stock; dwellings; typology; performance; code; methodology.

\section{Introduction}

Energy Performance on Albanian Buildings

Residential Building and dwellings typology

Residential Building typology by age and climate zones

The building typology was created on the last census data from 2011. The expertise used openly available data from the Albanian statistical office. As the CENSUS was not especially designed for gathering data for the energetic evaluation of the building stock, some data were not available on the required level of detail. Estimations were necessary to extrapolate data to the existing stock.

There is established a building typology consisting of 20 building types, based on the following considerations:

building type: the statistics distinguish between detached houses; semi-detached houses; row (terraced) houses and apartment buildings.

construction period: buildings are classified into six construction periods: buildings built before 1960; between 1961 and 1980; 1981-1990; 1991-2000 and 2001-2011. 
size of building: data were available for the number of dwellings in the building: buildings with one dwelling; two dwellings; three to four dwellings and five or more dwellings.

number of floors: buildings are classified into buildings with one floor; with two floors; three to five floors and six or more floors.

Further aspects were also analyzed, but as statistical data were not available per building type these aspects were not incorporated directly into the matrix:

climate zones: all data were given on a national level and for each prefecture.

construction materials: limited data was available.

heating systems and energy sources: national data was available.

Originally 24 building types were established but we decided to reduce the number of types and merged the buildings built between 2001-2005 and 2006-2011. The Albanian building typology is shown in Tab. 1.

Table 1. Albanian Residential Building Typology

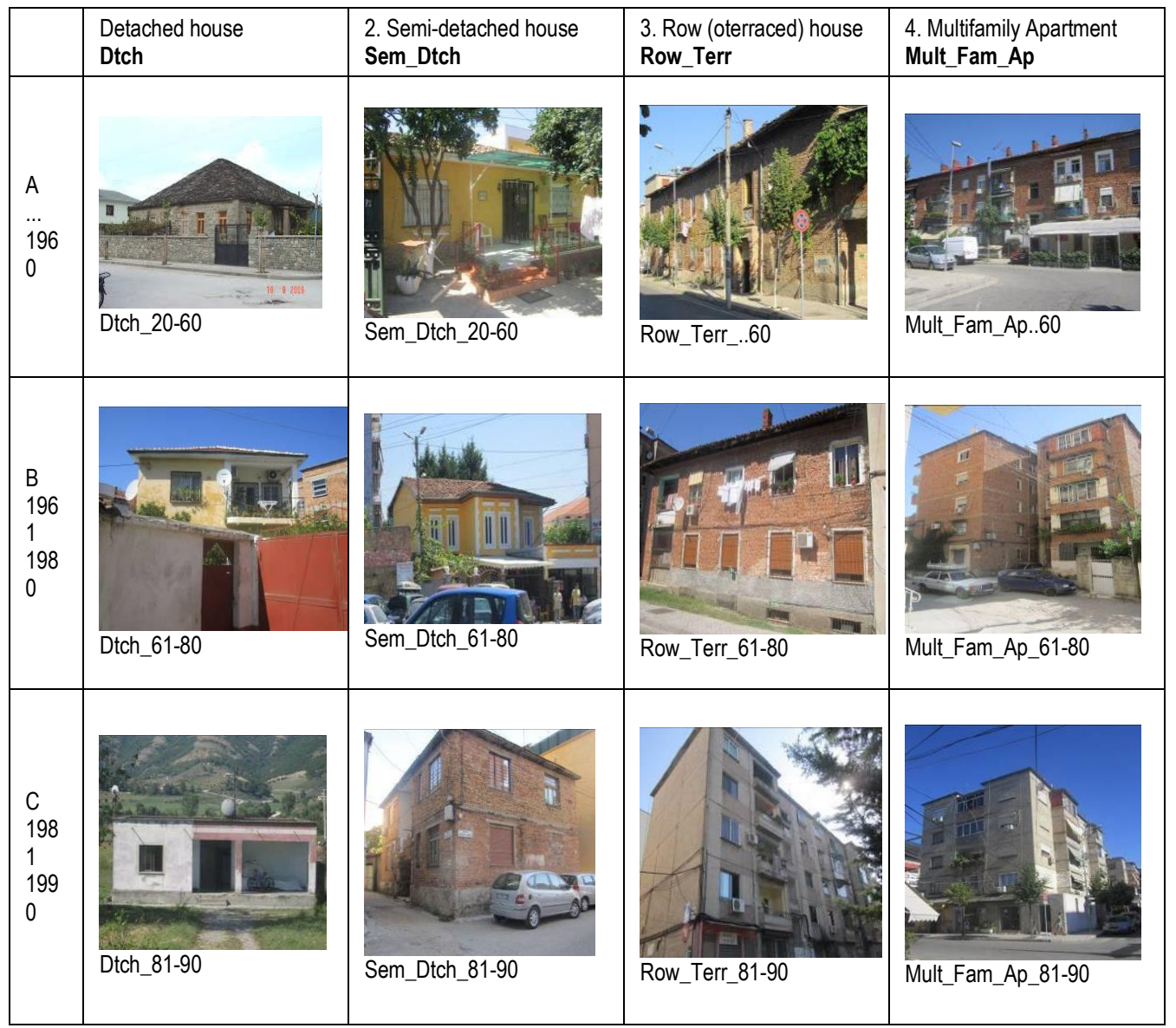




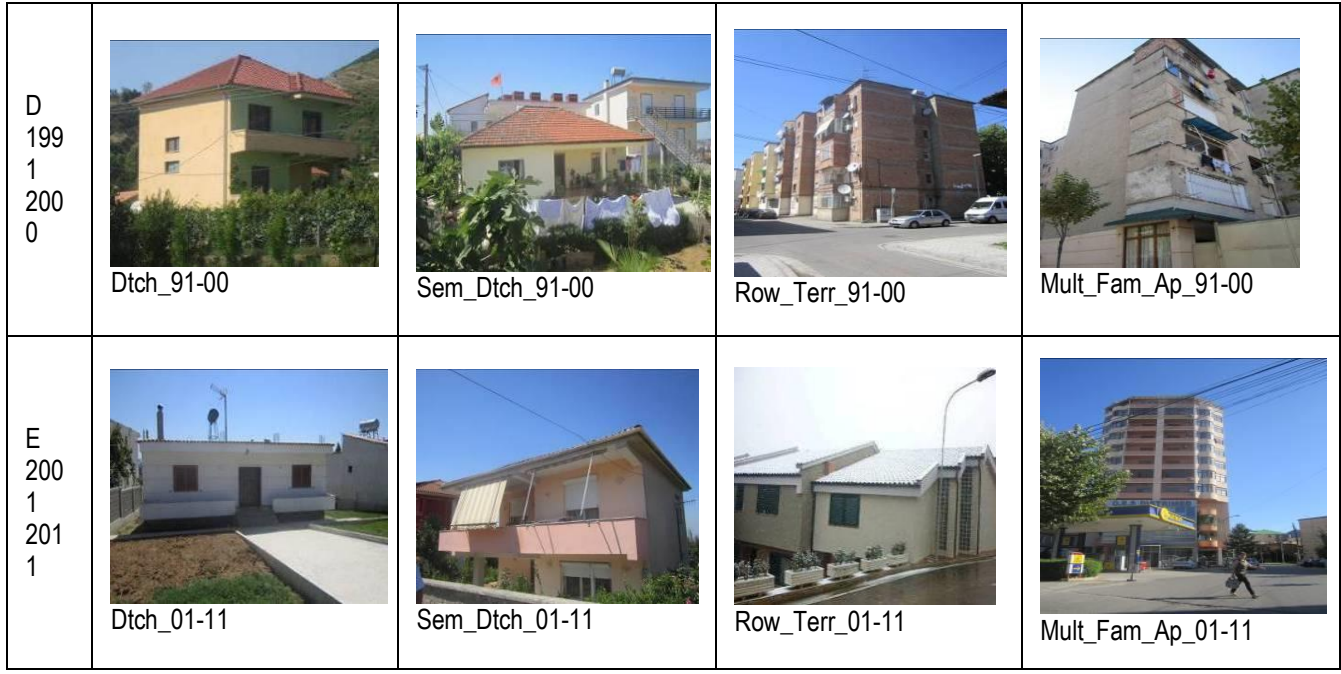

The building stock

The total number of residential buildings in Albania was 598,267 according to the 2011 census for a population of 2,821,977 (53.5\% of the population live in urban and $46.5 \%$ in rural areas) (INSTAT). The number of dwellings was 1,012,062, from which only 709,865 dwellings were inhabited. The number of private households in inhabited dwellings was 722,262.

There is classified the building stock into 20 building types. Figure 1 shows the number of buildings and dwellings in each building type. Detached houses built between 1991 and 2000 (type D1) represent the largest group with 108,752 buildings of this type. Apartment buildings from 1961-1980 and 1981-1990 are also significant regarding the number of dwellings. Fig 1 also shows the number of residential buildings with unknown period of construction and the non-inhabited buildings.

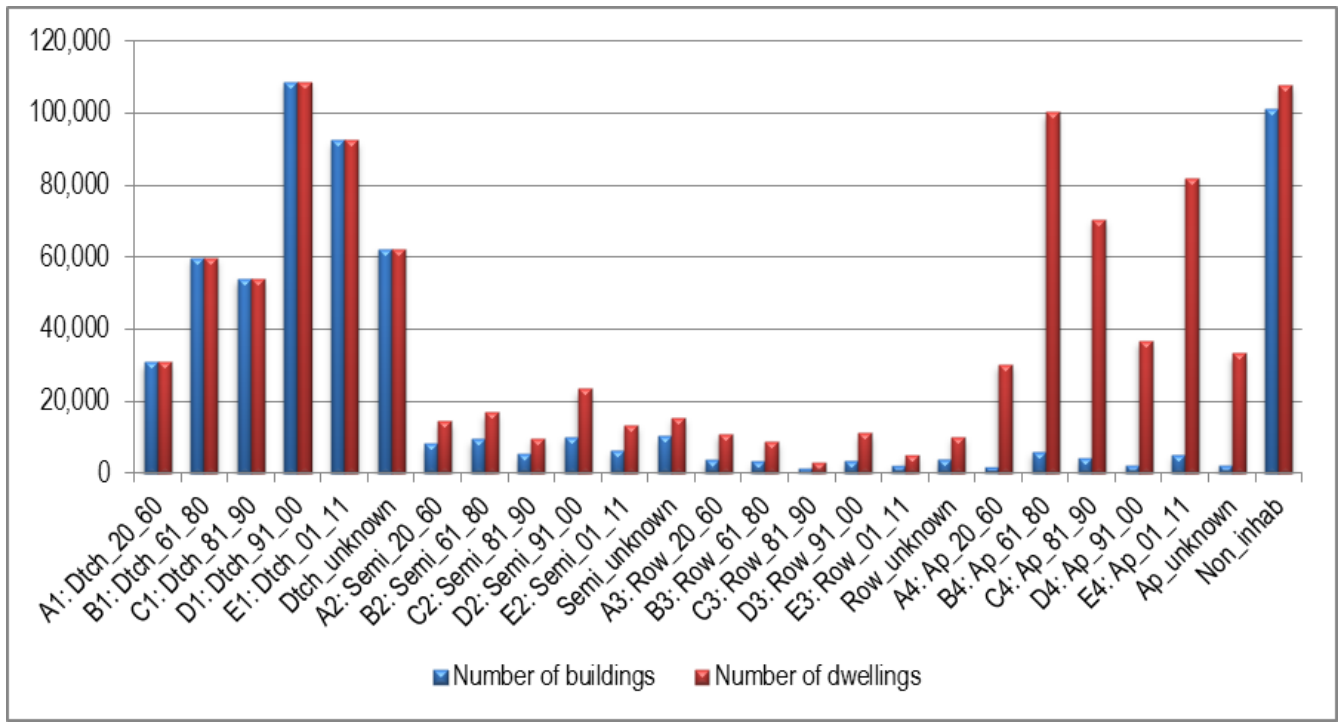

Figure 1: Number of residential buildings and dwellings by building type, based on INSTAT 2011

Residential buildings by building type 
Detached houses represent the highest share in the building stock with $83.7 \%$ of all buildings. Apartment buildings represent only $3.7 \%$ of the stock, however, these multistorey buildings include a large number of dwellings, representing about $35 \%$ of all dwellings. Semi-detached houses have a share of $9.4 \%$, while row/terraced houses are less significant.

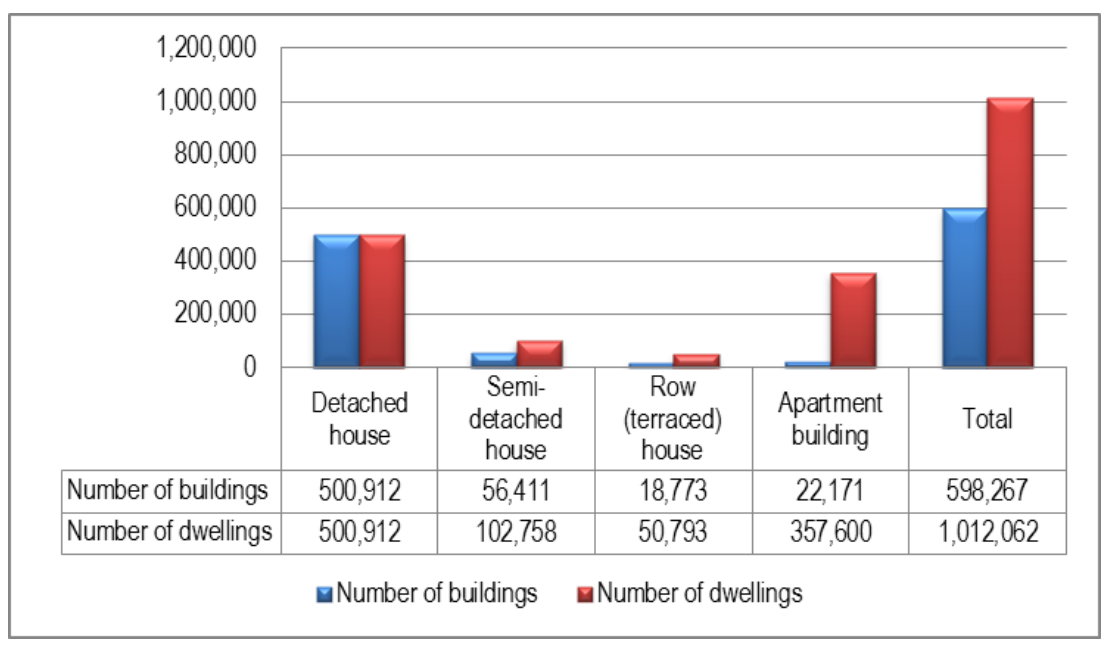

Figure 2: Number of residential buildings and dwellings by building type, based on INSTAT

Residential buildings by construction period

Only $7 \%$ of the existing building stock was built before 1960. After World War 2, from 1960 there was an upswing in the construction sector; especially large multifamily apartment buildings were constructed. $24 \%$ of buildings and $32 \%$ of the dwellings were constructed between 1961 and 1990. After 1990 we can observe a boom in the construction sector, but there is a shift toward detached houses from apartment buildings. After 2000 the number of new apartment buildings started to increase again. The construction period of $13 \%$ of the building stock is unknown and there is a large share of noninhabited buildings where the construction period is also not known ( $17 \%$ of buildings).

\begin{tabular}{|c|c|c|c|c|c|c|c|}
\hline \multirow{2}{*}{$\begin{array}{r}250,000 \\
200,000 \\
150,000 \\
100,000 \\
50,000 \\
0\end{array}$} & & & & & & & \\
\hline & $\begin{array}{l}\text { Up to } \\
1960\end{array}$ & $\begin{array}{l}1961- \\
1980\end{array}$ & $\begin{array}{l}1981- \\
1990\end{array}$ & $\begin{array}{l}1991- \\
2000\end{array}$ & $\begin{array}{l}2001- \\
2011\end{array}$ & $\begin{array}{l}\text { Unknow } \\
\mathrm{n} \text { period }\end{array}$ & $\begin{array}{c}\text { Non } \\
\text { inhabite } \\
\text { d }\end{array}$ \\
\hline Number of buildings & 44,195 & 78,495 & 64,943 & 124,474 & 105,983 & 78,809 & 101,368 \\
\hline Number of dwellings & 86,393 & 186,012 & 137,358 & 180,238 & 192,982 & 121,240 & 107,839 \\
\hline & & buildi & & nber 0 & ellings & & \\
\hline
\end{tabular}

Figure 3: Number of residential buildings by construction period (dwellings estimated only), INSTAT 2011

After 2000 the number of new apartment buildings started to increase again. The construction period of $13 \%$ of the building stock is unknown and there is a large share of non-inhabited buildings where the construction period is also not known ( $17 \%$ of buildings). 


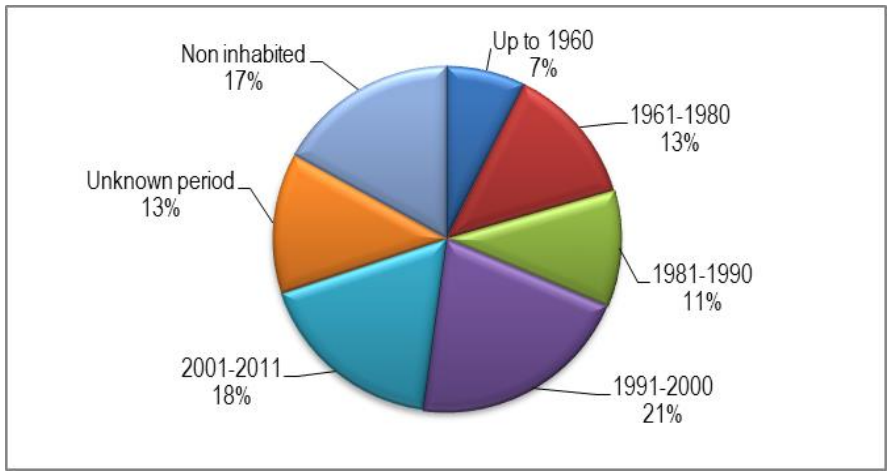

Figure 4: Share of residential buildings by construction period, based on INSTAT'11

Detached houses

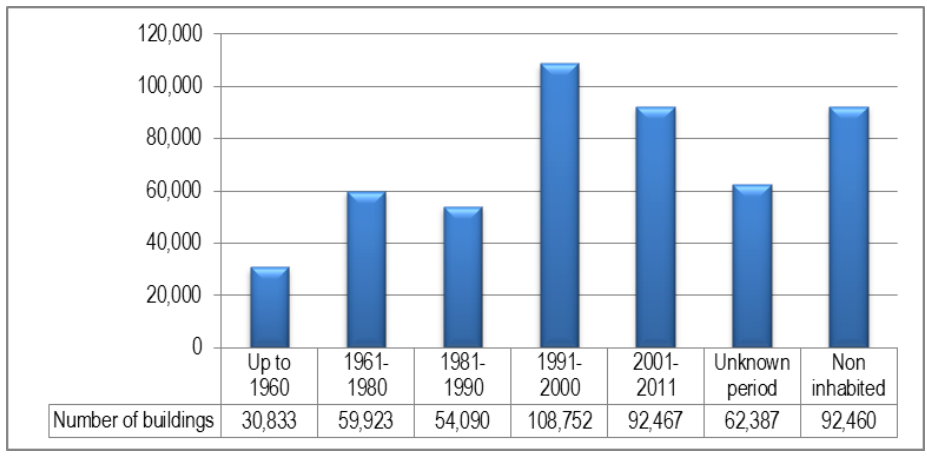

Figure 5: Number of detached houses by construction period, based on INSTAT

Most detached houses were constructed after 1960, with a peak between 1991 and 2000 when about $22 \%$ of the existing detached houses was constructed (Fig. 6). Also the first decade of the 21 st century had high construction rates (19\%). About $18 \%$ of the that houses are non-inhabited.

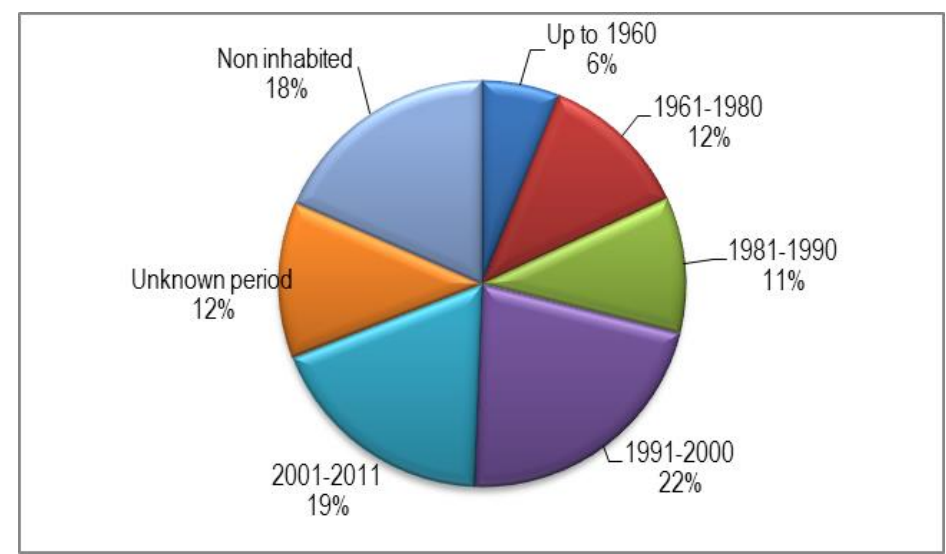

Figure 6: Share of detached houses by construction period, based on INSTAT 2011 


\section{Semi-detached houses}

The construction of semi-detached houses has been relatively constant: since $19605,000-10,000$ buildings of this type were constructed in every decade, with the largest numbers built between 1991 and 2000.

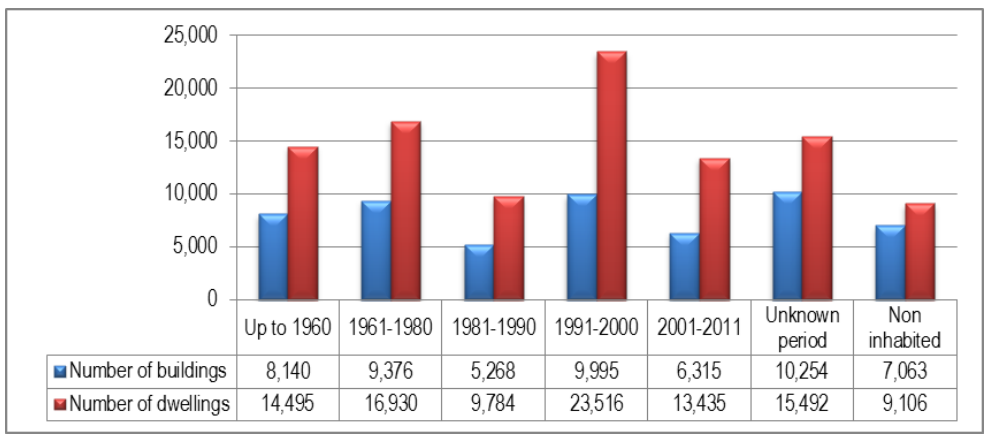

Figure 7: Number of semi-detached houses and dwellings in semi-detached houses by construction period 2011

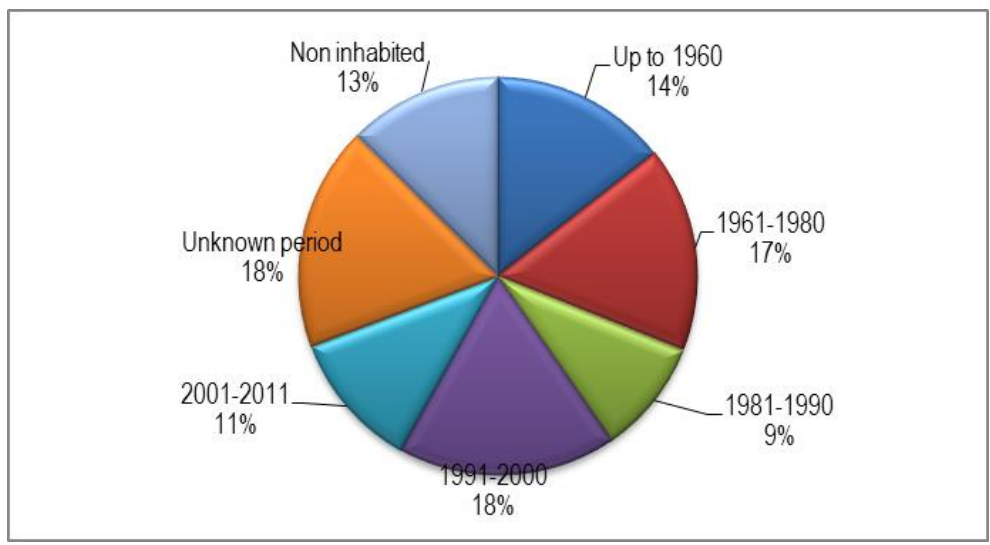

Figure 8: Share of semi-detached houses by construction period, based on INSTAT 2011

Row (or terraced) houses

After 1960, about 1300-3500 row houses were built in every decade, with the lowest number between 1981 and 1990 and the highest between 1991 and 2000.

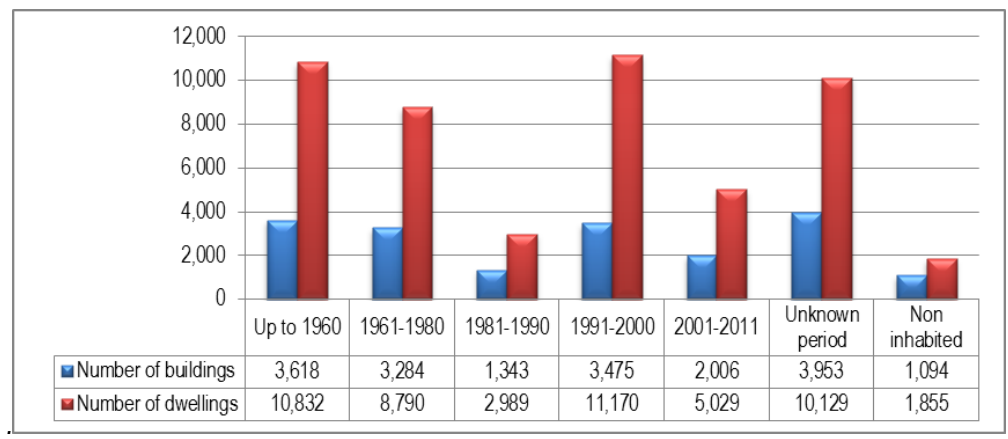

Figure 9: Number of row houses and dwellings in these buildings by construction period (dwellings),2011 


\section{Apartment buildings}

\begin{tabular}{|c|c|c|c|c|c|c|c|}
\hline \multirow[t]{2}{*}{ 158;明明 } & \multicolumn{5}{|c|}{ G1 } & 至 & \multirow[b]{2}{*}{$\begin{array}{c}\text { Non } \\
\text { inhabi } \\
\text { ted }\end{array}$} \\
\hline & $\begin{array}{l}\text { Up to } \\
1960\end{array}$ & $\begin{array}{c}1961- \\
1980\end{array}$ & $\begin{array}{l}1981- \\
1990\end{array}$ & $\begin{array}{l}1991- \\
2000\end{array}$ & $\begin{array}{l}2001- \\
2011\end{array}$ & $\begin{array}{c}\text { Unkn } \\
\text { own } \\
\text { period }\end{array}$ & \\
\hline Number of buildings & 1,604 & 5,912 & 4,242 & 2,252 & 5,195 & 2,215 & 751 \\
\hline Number of dwellings & \multicolumn{3}{|c|}{$30,234100,37070,495$} & 36,800 & 82,051 & 33,232 & 4,418 \\
\hline
\end{tabular}

Figure 10: Number of row apartment buildings and dwellings by construction period (dwellings in) 2011

Only $7 \%$ of the apartment buildings were built before 1960. The boom started after 1960, when large number of prefabricated buildings were built in the communistic era. The construction of apartment buildings slowed down after 1990, but during 2001-2011 more than doubled compared to the previous decade.

Number of floors

$85 \%$ of the Albanian residential building stock has one floor, while $10 \%$ has two floors, $4 \%$ three to five floors and only $1 \%$ six or more floors. During the last decade the construction of buildings with one to two floors decreased, the mid-size buildings remained about the same and the number of high-rise buildings with 6 or more floor and especially the number of buildings with more than 11 floors significantly increased (Simaku 2014)

\section{Non-inhabited buildings and dwellings}

The high number of non-inhabited buildings and dwellings is remarkable. There are 101,368 buildings which are noninhabited, while the number of non-inhabited dwellings is 302,197 . This includes 83,493 dwellings for secondary purposes or seasonal use, 218,514 vacant dwellings and 190 dwellings inhabited only by persons not object of the census. Vacant dwellings accounted for $21.6 \%$ of the dwellings in 2011 compared to only $11.3 \%$ in 2001.

\section{Climate zones}

The territory of Republic of Albania is divided into three climatic zones: zone A is the mildest along the sea, zone $B$ is the medium zone and zone $\mathrm{C}$ is the coldest in the mountainous area. About half of the buildings are located in climate zone $\mathrm{B}$, while climate zone $A$ has about one third of the buildings. The least buildings, about $16 \%$ of the stock are located in climate zone $\mathrm{C}$. The situation is similar regarding the number of dwellings.

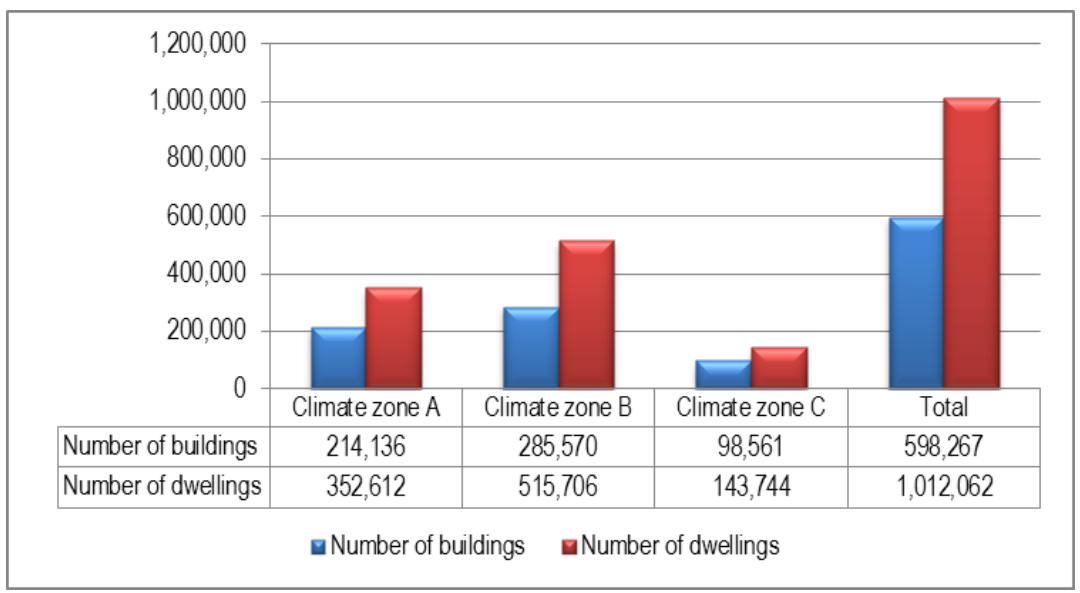

Figure 131: Number of residential buildings and dwellings by climate zone (dwellings only), INSTAT 2011 


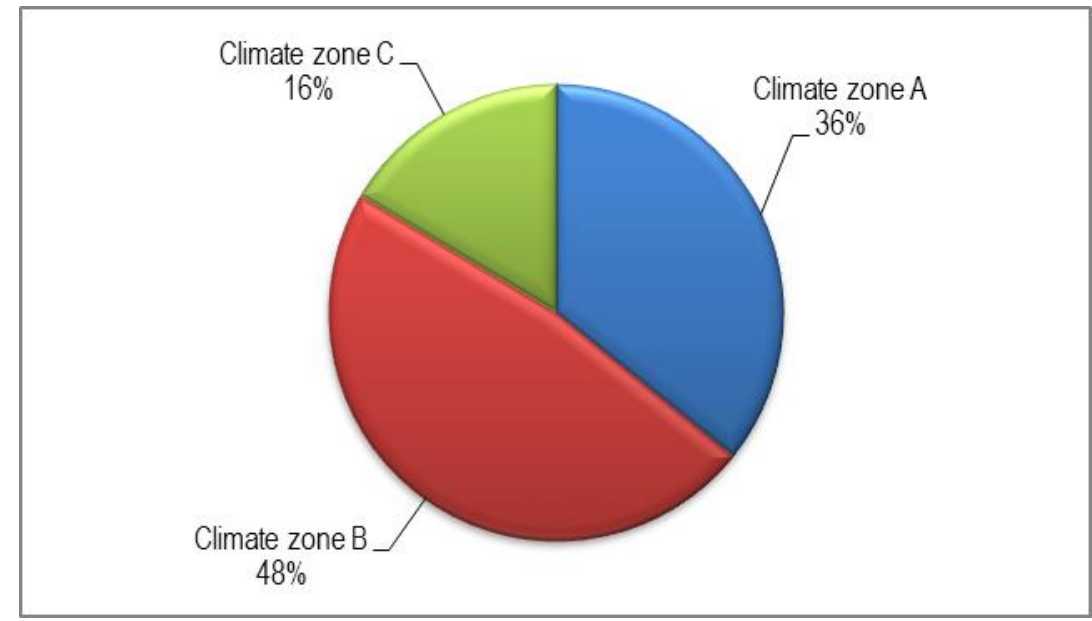

Figure 14: Share of residential buildings by climate zone, based on INSTAT 2011

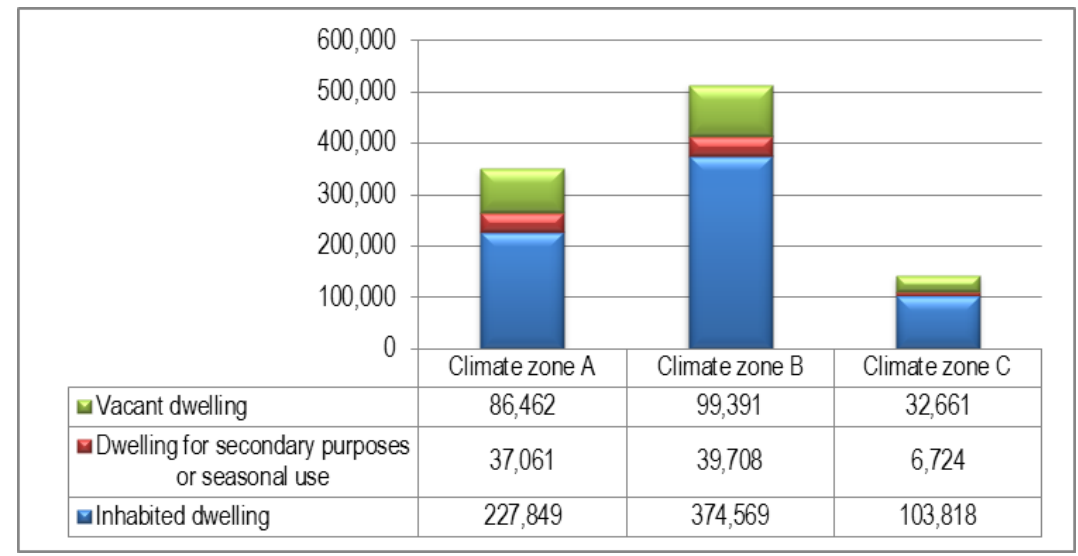

Figure 15: Number of dwellings by climate zone and occupancy, based on (INSTAT 2011)

\section{Trends}

The population of Albania is decreasing: in the last decade it fell by $9 \%$ from $3,069,275$ to $2,821,977$. Also the number of private households decreased compared to the previous census. The number of residential buildings in 2011 was 598,267 , which is not much higher than 512,387 in 2001, but the respective number of dwellings in 2011 is $1,012,062$ compared to 785,515 in 2001.

There are large regional differences in the country. Tirana region is the most affluent and buildings located here are in a better condition. The urbanization process is fast: in $2001,46.4 \%$ of the dwellings were in an urban area compared to $53.6 \%$ in rural area, while in $201153.9 \%$ were concentrated in urban and $46.1 \%$ in rural areas. There is also high rate of internal migration in the country especially towards the coastal area and Tirana.

Figure 16 and 17 show data for the number and floor area of building permits issued for new residential buildings. No statistical data was available for the demolition rate of buildings. 


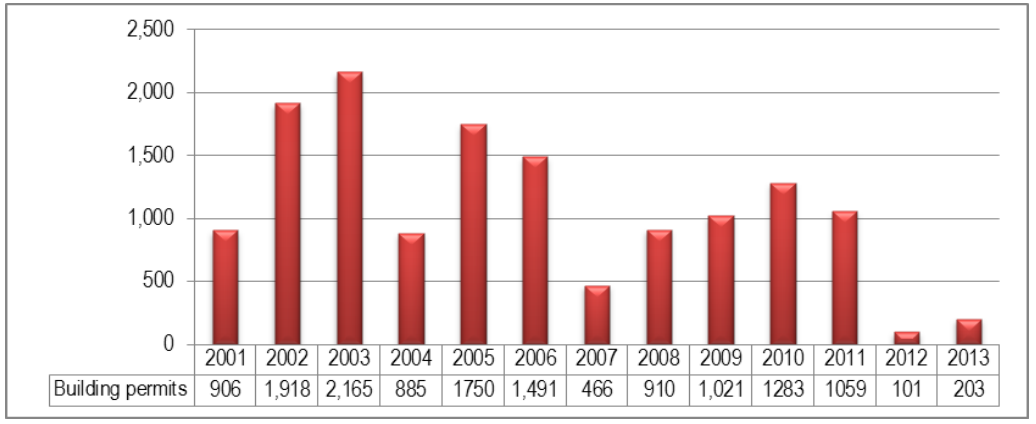

Figure 16: Building permits issued for new residential buildings, based on INSTAT'11

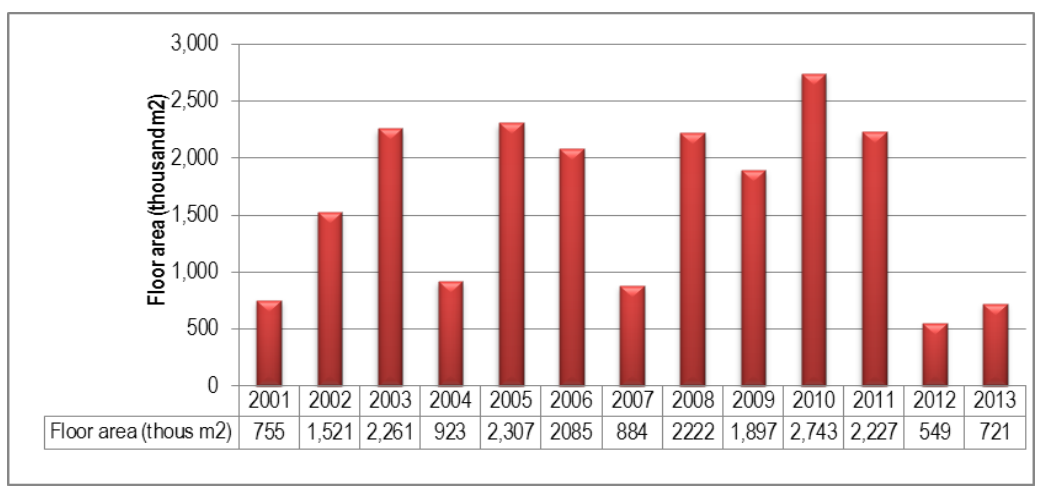

Figure 17: Floor area of building permits issued for new residential buildings, based on INSTAT'11

\section{Statistical data on construction materials}

We could not find data on construction materials in the 2011 census, but there were some data available in the 2001 census. At that time, according to the census there were 507,180 buildings in Albania. The majority of this building stock was built from brick or stone ( $88 \%$ ), and $5 \%$ was prefabricated. Even though the number of prefabricated buildings is lower than masonry buildings, they are usually multi-stores buildings containing many dwellings. Most of the apartment buildings constructed after 1960 were built with this technology. 'Other' materials include clay and adobe buildings.

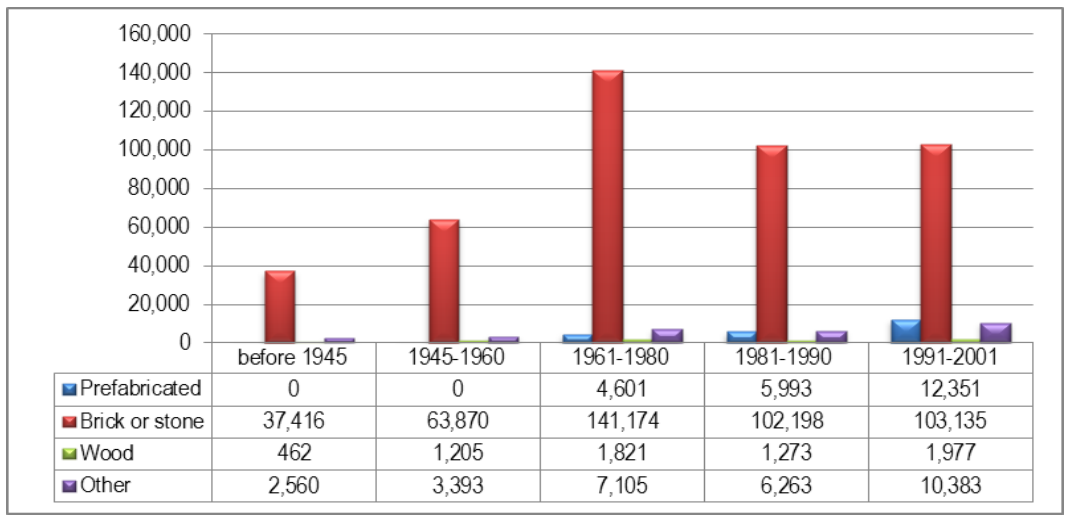

Figure 18: Buildings by construction period and main construction material, based on INSTAT'01 
Energetic quality of construction materials

Regarding the energetic quality of the building stock, apartment buildings built after 1960 with prefabricated technology usually have some insulation as this was part of the sandwich wall construction. Buildings built during the boom in the 1990 s are partly or insufficiently insulated. Even in the 2000s, the building codes were not strict enough and many buildings did not even comply with these requirements. Buildings are usually poorly insulated and have a high energy consumption. A part of the building stock has already been refurbished. The most common interventions were roof insulation and the replacement of single glazing with double glazing.

\section{Energy sources used for heating}

Data on the main type of energy used for heating are available for private households. According to the 2011 census, the most common energy source is still wood $(57.5 \%)$, followed by gas $(20.8 \%)$ and electricity $(15.4 \%)$ (fig 19$)$. Solar heating and other energy sources, such as coal and oil are negligible. About $6 \%$ of the households are not heated.

There is a large difference between rural and urban regions: in the rural area wood is much more dominant as a heating fuel than in urban areas. $85 \%$ of the rural households have wood-based heating systems. Poverty and inequality is a serious problem. In cities, the situation is more balanced: wood $(36.3 \%)$, electricity (24\%) and gas (31.3\%) are the three main energy sources (Fig. 20).

A difference can also be observed between the three climate zones. In the mountainous region of climate zone $\mathrm{C}$, wood is predominant, as it is used by $96 \%$ of the private households (Fig 21). In climate zone A and B, about half of the households are heated with wood, but electricity and gas also have a significant share. In the milder Climate zone A, about $9 \%$ of the households have no heating.

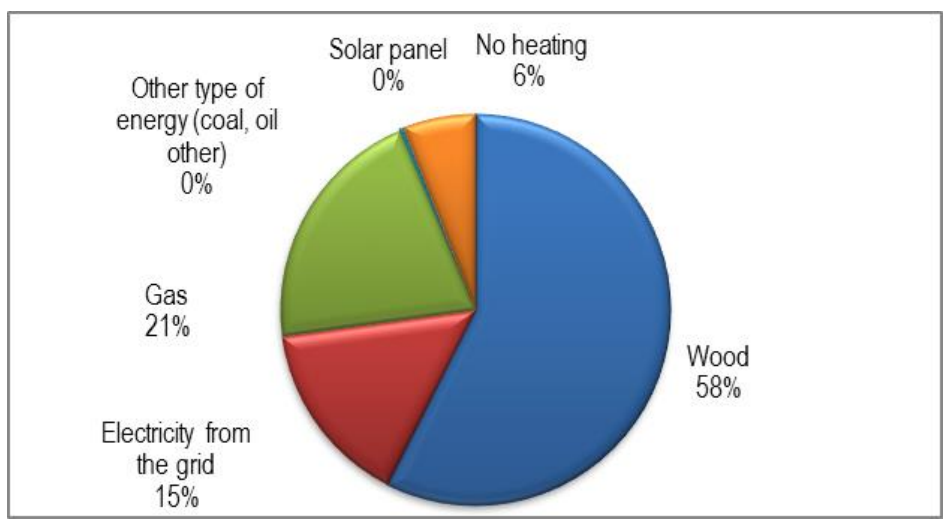

Figure 19: Private households by main type of energy used for heating, INSTAT 2011

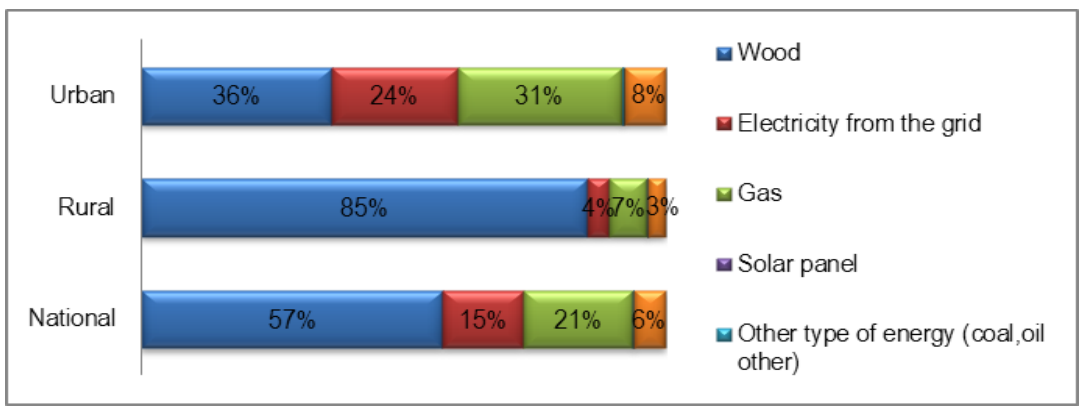

Figure 20: Private households by main type of energy source used for heating in urban and rural areas and the national average, INSTAT '11 


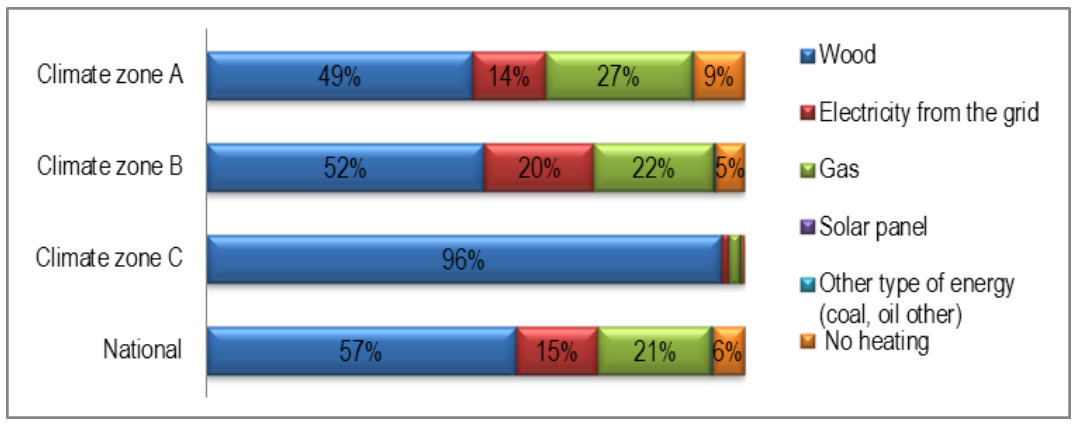

Figure21: Private households by main type of energy source used for heating according to climate zones, INSTAT 2011 The statistics by AKBN, however, show a different picture regarding the share of fuels. The share of electricity is much higher than in the census data. Electricity use also has an increasing trend: its share grew from $44 \%$ in 2012 to $50 \%$ in 2013. The consumption of wood and LPG is slowly decreasing. Regarding the climate zones, electricity is dominant in climate zone $\mathrm{A}$ and wood in climate zone $\mathrm{C}$. However, the values are rather different from the census.

Based on the consultation with the local experts, the difference can be explained by two factors. First of all, the census asked for the main type of energy source in the household. Nowadays many households in Albania purchase a secondary heating system, which is usually a heat pump to increase the thermal comfort in their dwellings. These secondary heating systems are not included in the census, but probably these are used for an increasing number of hours as their operation is more convenient than wood fueling. The second reason for the difference may be that some energy use may be misreported by the households in the census. Also, the AKBN figures show the fuel mix and not the share of households, and the used energy is directly proportional to its share in household numbers.

\section{Heating systems}

Corresponding to the main energy sources, stove is the most typical heating system $(63.3 \%)$, followed by electric heaters $(8.5 \%)$ and air heat pumps (air conditioners) (6\%). Only $3.2 \%$ of the private households have central heating (building or dwelling heating), while $4.4 \%$ has a fireplace (Fig 29). According to the experts, even where central heating systems exist, there is a lack of metering and controls to adjust temperature levels (Simaku 14B).

Regarding urban-rural differences, the same tendency can be observed as for the energy sources: in the rural areas stoves are predominant $(81 \%)$, followed by fireplaces $(7 \%)$. In urban areas, half of the households use stoves, with wood or gas fuelling. Electric heaters, heat pumps and other types of heating each account for about $10 \%$ in the households.

Similarly to the energy sources, there is also a difference in the heating systems between climate zones. In climate zone C, $95 \%$ of the households use stove for heating, with wood as an energy source. In climate zones $A$ and $B$, around $60 \%$ have stoves with most of the appliances operating with wood, but there are also other stoves. In the milder climate zone $\mathrm{A}$, fireplaces are also common (8\%). Electric heaters (9\%) and heat pumps (4\%) have a significant share in climate zone A, and in climate zone $\mathrm{B}(9 \%$ and $11 \%$, respectively). In climate zone $\mathrm{A}$ and $\mathrm{B}$, the share of other type of heating is around $10 \%$.

\section{Heated and unheated areas}

Traditionally several generations shared one building, occupying 2-4 rooms in the house (Simaku 14C). In winter, the „main room" or sitting room, usually the biggest room, was the only heated room where fire was kept during daytime in an open fireplace or a wooden stove. The bedrooms were not heated. This habit is still alive and in many buildings only part of the living area is heated.

According to AKBN, in 2008 only $35 \%$ of the living area was heated at the coastline and about $70 \%$ in the mountains. The trend is that the heated area increases. In 2012 , about $45 \%$ of the living area was heated in the coastline and $80 \%$ in the mountainous region.

\section{Mechanical cooling systems}

According to the census, $6 \%$ of the households are equipped with air conditioner: in climate zone A 4\%, while in Climate zone B $9 \%$ of the households have air conditioner. In the census questionnaire air conditioners are listed as a heating type. Generally, most of the cooling units are reversible, thus they can be used both for heating and cooling. According to the AKBN statistics, however the penetration of air conditioners is much higher, see Table. However, the use of these units as cooling devices cannot be supported by statistical data. 
Table2: Share of households with air conditioning in each climate zone (\%), source AKBN (Kelemen 15)

\section{Domestic hot water}

\begin{tabular}{|l|l|l|l|}
\hline Zone & A & B & C \\
\hline Urban & 40 & 25 & 15 \\
\hline Rural & 15 & 10 & 5 \\
\hline
\end{tabular}

The census did not include any questions about the hot water supply, but a general characteristic of an Alban household is that sanitary hot water is made using electrical hot water boiler. This is supported by the data provided by AKBN, according to which $62 \%$ of the energy for water heating is from electricity, and $23 \%$ from wood, LPG $10 \%$ and solar $5 \%$ on a national average. In climate zone $\mathrm{C}$, the ratio of wood is higher than in other climate zones, similarly to space heating.

Energy demand calculation using Building Code

The existing energy building Code indicator - Volumetric Coefficient for Thermal Looses, Gvt

In Albanian Code, the Volumetric Coefficient for Thermal Looses, Gut is used as performance indicator for new buildings (2003 to date). The Volumetric Coefficient for Thermal Looses, $G_{v}$ is the amount of heat transfer per heated volume of $1 \mathrm{~m}^{3}$ of building and per $1^{\circ} \mathrm{C}$ (or $1 \mathrm{~K}$ ) difference of indoor ( $t_{\text {br }}$ ) and outdoor $\left(t_{j}\right)$ temperature (in $\mathrm{W} / \mathrm{m}^{3} \mathrm{~K}$ ).

The Volumetric Coefficient for Thermal Looses, $\mathrm{G}_{\mathrm{vt}}$ is defined by the formula:

$$
G_{v}=\frac{Q}{V_{b}\left(t_{b r}-t_{j}\right)} \quad\left[\mathrm{W} / \mathrm{m}^{3} \mathrm{~K}\right]
$$

Where: $\quad G_{v} \quad=$ volume coefficient of global losses $\left(\mathrm{W} / \mathrm{m}^{3}{ }^{\circ} \mathrm{C}\right)$

$$
\begin{array}{ll}
\mathbf{Q} & =\text { total losses }(\text { Watt }) \\
V_{\boldsymbol{b}} & =\text { inhabitable volume }\left(\mathrm{m}^{3}\right)
\end{array}
$$

According to the Regulations, this coefficient must not exceed normative values $\mathrm{Gvt}_{\mathrm{vt}}^{\max }$, which have different recommended values for 3 different climatic zones, and depends slightly by building's and dwelling shape as a whole considering the ratio $\mathrm{S} / \mathrm{V}$, where $\mathrm{S}$ is the building's envelope area from which the heat occurs, and $\mathrm{V}$ is the heated volume:

\section{$G_{v t} \leq G_{v t} \max$}

This indicator is an old approach used in 90-th and does not correspond to the EN standards and methodologies for expressing energy performance indicators. Nevertheless the results are proven for more than 12 years and still are relevant and correct on energy savings calculations.

The existing method of calculation of thermal losses by the Albanian Energy Building Code, DCM No.38, 16/01/2003.

The total heating losses $(\mathbf{Q})$ of the building are equal with the sum of thermal losses for the ventilation or for air change $\left(Q_{\text {vent }}\right)$ and thermal transmission losses $\left(Q_{\mathrm{tr}}\right)$ which, by itself, is a sum of losses through the transmission on the flat area of the envelope $\left(\mathbf{Q}_{\mathrm{pl}}\right)$ and the losses through the transmission of cold bridges or thermal linkages $\left(\mathbf{Q}_{\mathrm{ny}}\right)$.

\section{$Q=Q \operatorname{Qtr}+Q v e n t=(Q p l+Q n y)+Q v e n t$}

To this balance we add up or subtract some positive an/or negative gains which are studied in detail; these supplements are represented by ( $\left.\pm Q_{\text {shtesa }}\right)$. Thus we have the following relation: 
$Q=Q_{\text {tr }}+Q_{\text {vent }}=\left(Q_{\text {pl }}+Q_{\text {ny }}\right)+Q_{\text {vent }} \pm Q_{\text {shtesa }}$

The indoor temperature to be used for calculation tbr

In different Albanian books or booklets which deal with heating we can find different fixed temperatures for different buildings or localities. For calculation purposes, understanding that in buildings these temperature differ slightly from each-other we have to take into consideration the following:

Residences:

$20^{\circ} \mathrm{C}$

Local of common use or for a number of people:

$17^{\circ} \mathrm{C}$

These temperatures can be increased slightly due to heating gains caused by people who live in, from the heating given out from different appliances, from solar gains, lighting, electric appliances, etc. The increase does not exceed 2 or $3^{\circ} \mathrm{C}$.

In general, all living spaces in a residence building should be around $20^{\circ} \mathrm{C}$. Referring to the different places and localities such as working environment, dining room, bathrooms, garages, etc., the temperature has different levels. There are some approximate temperatures that are available for calculation purposes:

\begin{tabular}{llll} 
Room & Dinning/sleeping & Seating/Kitchen & Bathrooms \\
\hline Day & 18 & 20 & 22 \\
Night & 17 & 16 & 20
\end{tabular}

These temperatures are settled in stable and standard conditions of humidity of the air, wall's temperature and the speed of the indoor air which is not the case in practice. For sure these "predetermined" temperatures are used as such throughout the cold season as everything depends on the variation of the outdoor temperatures which in a way affect the indoor ones taken for calculation. The study explain this "strict" attitude toward these recommended temperatures are not the final solution for the exact thermal calculation because there exist other factors such as: the radiation of the objects which might heat or not, the type of heating, etc., (a whole radiant heating or partial convective). Also, another concept is that the average superficial temperature which is of a higher difference in relation to the outdoor temperature than due to the indoor one used for the calculation.

The outdoor temperature to be used for calculation tout

In order to keep a constant indoor temperature of the buildings, it is necessary for the installed power to enter the building according to the variation of a comparative temperature so that to decrease or to increase time after time or to go up to the maximum values which correspond to the "outdoor temperature used for calculation". As a result the installation of the building is designed to be done according to the minimal outdoor temperature which is used as a base for the project. In other words, this is a referring temperature which according to the experience of many developed countries is accepted to be the average temperature of a certain region measured in the five coldest days during the three coldest months of the last three years.

As specialized institutions of every country must give an official precise table of temperatures, the data of Albania exists in such a table, but the temperatures of the last 5 years are not included. Anyway the table has approximate values which are used by our specialists (compiled by Hydrometeorology Institute since 1984). According to the literature a map can be compiled in order to give the temperatures of the regions on $200 \mathrm{~m}$ height and with a difference by $1^{\circ} \mathrm{C}$. This data are indispensable for the designers of the residences or of the social buildings to undertake some measures concerning thermo insulation and the sizing the heating system installation.

\begin{tabular}{|l|l|l|}
\hline & City & Outdoor temp. used for calculation $\left({ }^{\circ} \mathrm{C}\right)$ \\
\hline 1 & Saranda & 4 \\
\hline
\end{tabular}




\begin{tabular}{|l|l|l|}
\hline 2 & Kavaja & 1 \\
\hline 3 & Lushnja & 1 \\
\hline 4 & Vlora & 0 \\
\hline 5 & Durresi & 0 \\
\hline 6 & Delvina & 0 \\
\hline 7 & Berati & -1 \\
\hline 8 & Elbasani & -1 \\
\hline 9 & Tirana & -1 \\
\hline 10 & Lezha & -1 \\
\hline 11 & Kuçova & -1 \\
\hline 12 & Fieri & -1 \\
\hline 13 & Gjirokastra & -2 \\
\hline 14 & Shkodra & -5 \\
\hline 15 & Pogradeci & -5 \\
\hline 16 & Korça & -10 \\
\hline 17 & Kukesi & -12 \\
\hline 18 & Peshkopia & -13 \\
\hline
\end{tabular}

Thermal losses calculation due to infiltration and ventilation of building: Qvent

It means also the "air change" and with that notion we mean heated air movement from indoor to outdoor of the building by different reasons such as, infiltration by non-fittings of the doors and windows, and also by impossibility to have "hermetic" fittings. Another reason for the infiltration is the bad use of openings, like doors and windows for any kind of reason: odors, overheating, quick ventilation and many different reasons.

\section{Mechanical ventilation}

Mechanical ventilation of the building area is an organized air movement from indoor to outdoor and replacement of the warm by the fresh air which comes from outside and this exchange causes a thermal supplementary load.

Corresponding losses, which are differently called "losses due to infiltration and ventilation" and also, even more important because of the losses which associate this process:

the difference between indoor and outdoor temperature is big. ( $\mathrm{t}_{\text {brend }}$ - tjash) the flow of $Q$ due to air change is big and equal:

$$
\left.Q_{\text {vent }}=0.34 \operatorname{Vn}\left(t_{\text {in }}-t_{\text {jasht }}\right) \quad \text { [Watt }\right]
$$

Where: Qvent = the losses in (watt)

$$
\begin{array}{ll}
0,34 & =\text { the average value of the specific heat capacity of air }\left(\mathrm{W} / \mathrm{m}^{3} \mathrm{~K}\right) \\
\mathbf{V} & =\text { volume of local }
\end{array}
$$

$\mathbf{n}=$ number of air changes of the local considered.

$\mathrm{t}_{\mathrm{br}}, \mathrm{t}_{\mathrm{jash}}=$ indoor and outdoor temperature in Celsius $\left({ }^{\circ} \mathrm{C}\right)$

For the residences "the hourly rate of the air change of the space volume heated air in a room for different climatic condition of a normal winter" is fixed number. It is a relation between hygienic needs and the energy consumption. In reality, the percentage of air renovation might be much higher or much lower depending on some factors such as: the wind presence and/or its preasure, quality of the fittings of different doors and windows and also exposure of façades and openings. By 
experience this percentage varies as 1 to 10 . The official texts take this into account but their application is very delicate. In the individual houses the permanent ventilation is obligatory for the kitchen, toilets and bathrooms.

The heat losses due to heat transfer through walls and thermal bridges. $Q_{t r}$ and $Q_{n y}$

The main part of the indoor heat of the building goes out through the partitions. These losses are even more important because:

the difference between the indoor temperature and the outdoor one is big ( $\left.\mathrm{tbr}_{\mathrm{br}}-\mathrm{t}_{\mathrm{jash}}\right)$

the coefficients $K^{1}$ of the heat transmittance through the different outdoor building's elements envelopes in contact with indoor partitions' $F$ areas.

These losses are represented by the following formula only for a part of the flat partition:

$$
Q_{t r}=K S\left(t_{\text {in }}-t_{\text {out }}\right)
$$

where Qtr - superficial losses of the partitions (Watt)

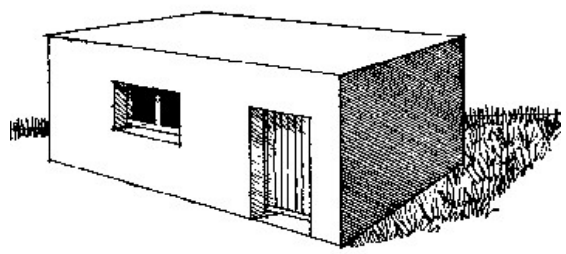

$\mathrm{K}$ - coefficient of the partition superficial transmittance $\left(\mathrm{W} / \mathrm{m}^{2}{ }^{\circ}{ }^{\circ} \mathrm{C}\right)$

$F$ - area of the partition taken into consideration $\left(\mathrm{m}^{2}\right)$

Coefficient $K$ varies according to the nature and thickness of the materials. It is calculated for a given locality to make separated calculations for each of the partition part Fig:

$\begin{array}{lll}\text { Wall } & \text { Coefficient K1 } & \text { Area F1 } \\ \text { Window, wooden frame } & \text { Coefficient K2 } & \text { Area F2 } \\ \text { Wooden Door } & \text { Coefficient K3 } & \text { Area F3 }\end{array}$

Thermal superficial losses of these layers are equal to:

$$
Q_{t r}=\sum\left(Q_{p l}+Q_{n y}\right)=\left(\sum K_{i} F_{i}+\sum K_{n y}^{i} L_{n y}^{i}\right)\left(t_{i n}-t_{\text {out }}\right)
$$

This coefficient $K_{n y}$ is given for one linear meter and is multiplied by length of the same linkage. As a result:

$$
Q_{n y}=K_{n y} L\left(t_{\text {in }}-t_{\text {out }}\right)
$$




$\begin{array}{ll}\text { Qny } & =\text { linear losses of the thermal linkage }(\mathrm{W}) \\ \mathrm{K}_{\text {ny }} & =\text { heat transmission coefficient for one } \mathrm{ml} \text { linkage }(\mathrm{m}) \\ \mathrm{L} & =\text { length of linkage }(\mathrm{m})\end{array}$

The total thermal losses for the whole building are:

$$
Q_{t r}=\sum\left(Q_{p l}+Q_{n y}\right)=\left(\sum K_{i} F_{i}+\sum K_{n y}^{i} L_{n y}^{i}\right)\left(t_{\text {in }}-t_{\text {out }}\right)
$$

The thermal balance of the heated area: volume coefficient of global losses $G_{v}$

Altogether, the maximum thermal losses for one building are given as a sum of losses due to transmission and of losses due to air change (infiltration, controlled or not controlled ventilation):

$$
Q=Q_{t r}+Q_{v e n t} \quad[\text { Watt }]
$$

where: $Q_{\mathrm{tr}}=$ losses for the transmission through flat surfaces and linkages (Watt)

$$
Q_{\text {vent }} \quad=\text { losses for the air change (Watt) }
$$

When it comes to examine carefully some buildings we will see that the same voluminous do not have the same thermal losses. This is because buildings change a lot from one to another. Following this idea, building coefficient wall-window is not the same; also their structure changes, they have different orientations, different exposure to the wind, they are situated in different regions, etc.

Based on these differences the volume coefficient of global losses, $G_{v}$ is introduced:

$$
G_{v}=\frac{Q}{V_{b}\left(t_{\text {in }}-t_{\text {out }}\right)} \quad \text { ne }\left[\mathrm{W} / \mathrm{m}^{3{ }^{\circ} \mathrm{C}}\right]
$$

where: $\mathbf{G}_{\mathrm{v}}=$ volume coefficient of global losses $\left(\mathrm{W} / \mathrm{m}^{3}{ }^{\circ} \mathrm{C}\right)$

$$
\begin{array}{ll}
\mathbf{Q} & =\text { total losses (Watt) } \\
\mathbf{V}_{\mathbf{b}} & =\text { inhabitable volume }\left(\mathrm{m}^{3}\right)
\end{array}
$$

In its essence, the volume coefficient of global losses is the thermal efficiency of the construction. To determine it we can calculate the losses due to transmission with the help of the superficial corrected coefficient " $K_{c}$ ", which is more complex than the previous calculated coefficient " $K$ ". This happens because the wind condition and the superficial size of the windows and doors are related to the architectural style of building. It is difficult to exactly find the $G_{v}$ coefficient, but its use quickens the procedure of numerous calculations. In practice, the study of this coefficient for different regions and different buildings provides a better experience for the engineers concerning heat efficiency in buildings.

The Climatic Zones: the limit values of $\mathrm{G}_{\mathrm{v}}$

As I have mentioned before, in Albania does not exist maps, which show the climatic zones of the country with the calculated and defined minimal temperatures. Although, it is given a table for different districts of Albania and for the sake of calculations let's consider these districts as climatic zones. The coefficient Gv must change according to the thermal insulation of building and is obvious that thermal insulation is stronger in the cold zones. Based on these factors here is a table: 


\begin{tabular}{|c|c|c|c|c|c|c|}
\hline Heating type & \multicolumn{3}{|c|}{ Non electric } & \multicolumn{3}{|c|}{ Electric } \\
\hline $\begin{array}{l}\text { Climate zone } \rightarrow \\
\text { Inhabitant volume } V_{b} \downarrow\end{array}$ & A & B & C & A & B & C \\
\hline$V_{b}<150 m^{3}$ & 1,60 & 1,75 & 2,00 & 1,30 & 1,35 & 1,45 \\
\hline $150 m^{3}<V_{b}<300 m^{3}$ & 1,45 & 1,60 & 1,90 & 1,20 & 1,25 & 1,35 \\
\hline $300<V_{b}$ & 1,30 & 1,45 & 1,75 & 1,10 & 1,15 & 1,25 \\
\hline
\end{tabular}

Zones $\mathrm{A}$ are with a minimal outdoor temperature used for calculation +5 to $-1^{\circ} \mathrm{C}$

Zones $\mathrm{B}$ are with a minimal outdoor temperature used for calculation -1 to $-5^{\circ} \mathrm{C}$

Zones $C$ are with a minimal outdoor temperature used for calculation -5 to $-15^{\circ} \mathrm{C}$

\section{FROM INSULATION LAYER TO ENERGY PERFORMANCE INDICATOR}

The principle of the Albanian regulation, as proposed in the published legislative act Decision Council of Ministers, $\mathrm{Nr} .38,16 / 01 / 2003$, is beyond any doubt correct. Aim of the contemporary regulation is to ensure the maximum achievable energy savings, but not to impose an unbearable financial burden on the building constructors and prospective buyers. In order to achieve such an aim, the idea of introducing an energy loss coefficient, like the Gv, that will depend on the climatic zones of the country's regions, and that will determine building thermal losses in terms of conductivity and ventilation is definitely the right one. In that sense, considering the climatic conditions and the prevailing energy use patterns of Albania, a consumption of in between 50 to $100 \mathrm{kWh} / \mathrm{m} 2$ and year can be considered as feasible, with respect to the development monitored in neighboring countries, like Greece, Serbia, Montenegro, Macedonia and Kosovo (Fig 22).

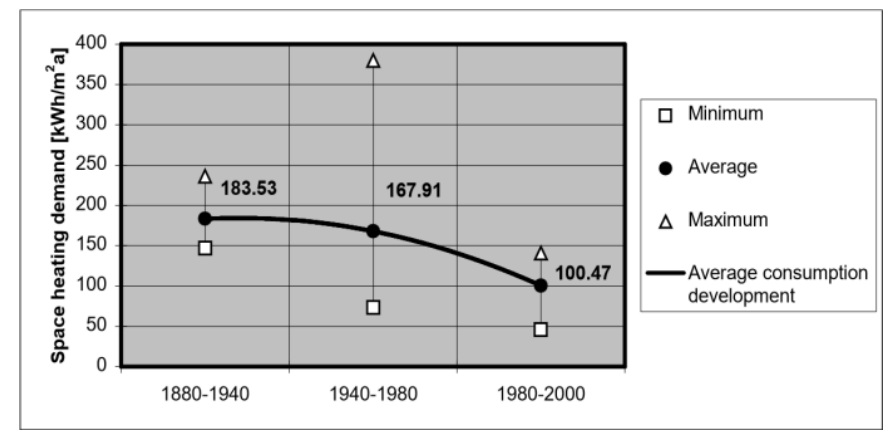

Figure 22. Development in energy consumption in three Southeastern European countries

This figure (Energy Performance - EP), else known as the annual specific energy demand which refers to the square meter of a building's heated surface, is comparable to those of other Southern East Balkan Countries. Both as a physical property and as numerical value it inscribes very well the new European directive for the EP of buildings (EPB Directive 2010/31/EC.

In terms of renovation of existing buildings, increasing EE measures in existing stock, it can be achieved with a reasonable quality and quantity of thermal insulation, with reasonable double glazed windows and doors and with a minimum of ventilation guaranteeing good levels of indoor air quality and also thermal comfort. At the same time, it complies with the minimum temperature and ventilation rates foreseen in the Albanian Decision Council of Ministers, Nr.38, 16/01/2003 

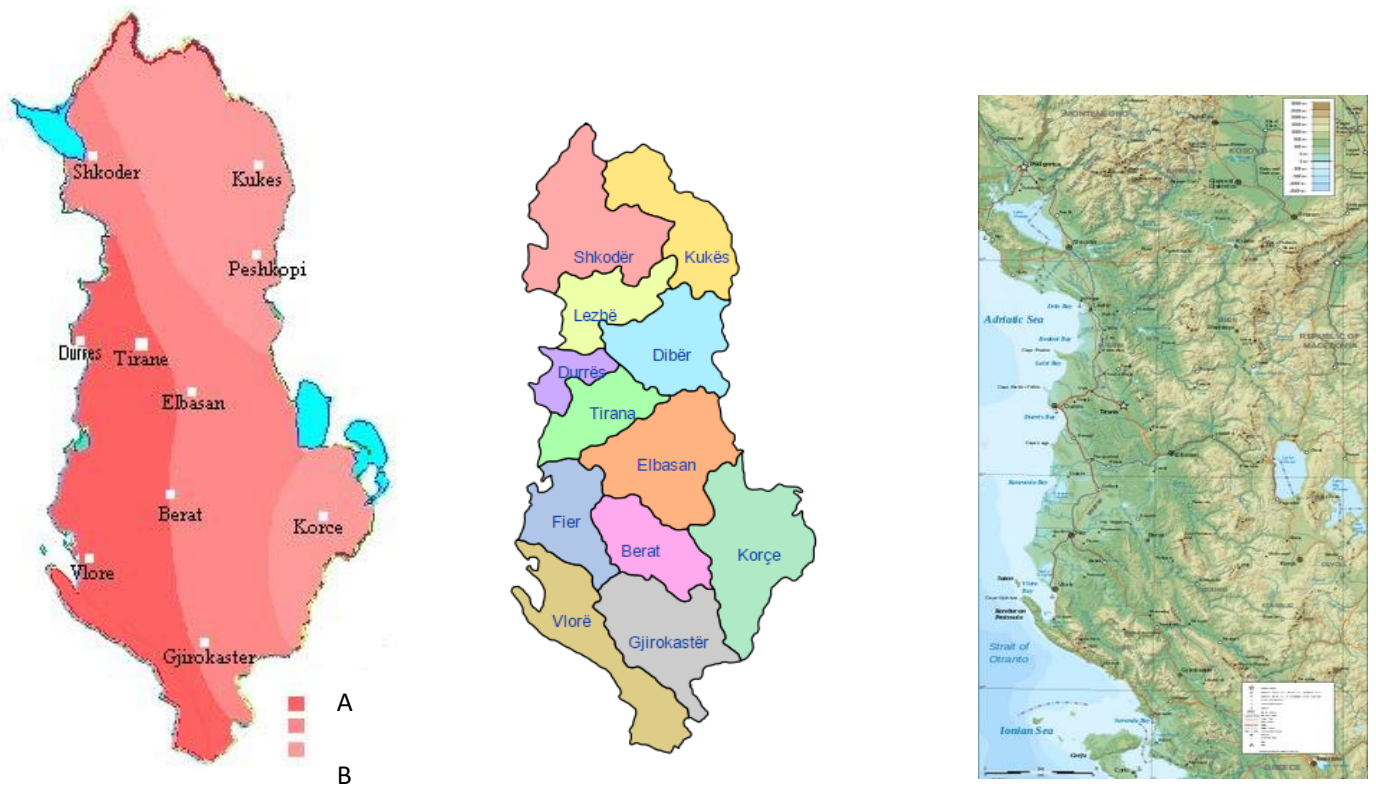

Figure 3: Climate zones and municipalities in Albania (Simaku, 2014d; "Wikipedia 2015; "Wikimedia" 2015)

The existing Method on Determination of the energy loss coefficient $\mathrm{Gv}$

In terms of a regulation, this performance measurement can be described by the energy loss coefficient Gvo (Gv overall), as foreseen in the Albanian Decision Council of Ministers, (DCM) Nr.38, 16/01/2003, well known as Energy Building Code (EBC). In order now to be able to achieve the energy performance needed, the new regulation will have to foresee certain limits for both components, of which $G v$ consists, namely: $G_{v_{t}}=(S / V) \cdot k_{m}$, for volume coefficient of global losses (transmissibility) and $\mathbf{G v}_{\mathbf{v}}$ for ventilation

And in order to ensure this there will have to be established that $G v_{t} \leq G v_{t} \max$

That in buildings with natural ventilation it is impossible to ensure that $G v_{v} \leq G v_{v} \max$

Once it therefore, can only consider a certain constant $\mathbf{G} \mathbf{v}_{\mathbf{v}}$ for the comparison reasons. In that sense, and also, given the fact that ventilation is not far exploded and the most difficult component of energy losses to control, it is particular significant that both partial Gv's should be the subject of a limit or fix number, in order to be in practice fairly sure of achieving a satisfactory result.

Determination of the Transmissibility losses coefficient Gvt

It has to be noted, that in the considerable number of buildings constructed after 1998 that is after the introduction of the 4th generation of energy regulations ventilation accounts for as much as 50 to $60 \%$ of the total energy consumption. Obviously, that is reasonable that the transfer losses coefficient Gvt foreseen by the existing regulation should be able to ensure the respective energy consumption. With respect to the data published in the Albanian Energy Building Code, DCM Nr.38, 16/01/2003, concerning the climate, the indoor temperatures and the building materials and techniques, the proposed values for the heat transfer losses coefficient Gvt would have to be the ones presented in the following 


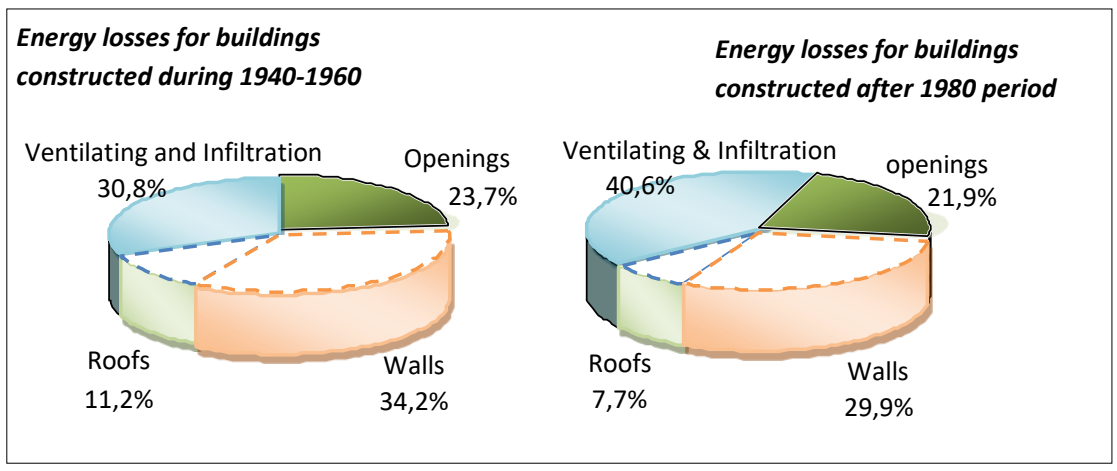

Table 3. The research done by Gj.S, it is the only way to transpose the EBC to the Energy Performance terms.

\begin{tabular}{|c|c|c|c|c|c|c|c|}
\hline \multicolumn{2}{|c|}{ Climatic zones } & \multicolumn{2}{|l|}{ A } & \multicolumn{2}{|l|}{$B$} & \multicolumn{2}{|l|}{ C } \\
\hline$S / V \downarrow$ & $\mathrm{DD} \rightarrow$ & 900 & 1500 & 1500 & 2500 & 2500 & 3000 \\
\hline 0,2 & & 0.216 & 0.186 & 0.186 & 0.170 & 0.170 & 0.149 \\
\hline 0,4 & & 0.413 & 0.362 & 0.362 & 0.338 & 0.338 & 0.299 \\
\hline 0,6 & & 0.592 & 0.525 & 0.525 & 0.498 & 0.498 & 0.440 \\
\hline 0,8 & & 0.752 & 0.700 & 0.700 & 0.637 & 0.637 & 0.576 \\
\hline 1 & & 0.940 & 0.846 & 0.846 & 0.795 & 0.795 & 0.705 \\
\hline
\end{tabular}

Table 4. Volume coefficient of global losses Gvt

As it was mentioned before, all the calculations are assumed to be done on the basis of indoor temperature ( $\left.\mathrm{t}_{\mathrm{in}}\right)$ and the outdoor one used for calculation ( $t_{\text {out }}$ ), both constant. For the calculation purpose, this heating regime is called "permanent regime" or as we call it usually "stationary regime". These "fixed" calculations will be used when we size the surface of the radiators and/or their installed capacity. As a matter of fact, their maximum or designed capacity does not "offset" their cost when the outdoor temperature is higher than that chosen as minimum for the sake of calculation. The implementation of these coefficient will result in an average energy consumption due to volume coefficient of global losses that is presented in Table 5.

\begin{tabular}{|c|c|c|c|c|c|c|c|}
\hline \multicolumn{2}{|c|}{ Climate zones } & \multicolumn{2}{|l|}{$\mathrm{A}$} & \multicolumn{2}{|l|}{$B$} & \multicolumn{2}{|l|}{$\mathrm{C}$} \\
\hline$S / N \downarrow$ & $\mathrm{GD} \rightarrow$ & 900 & 1500 & 1500 & 2500 & 2500 & 3000 \\
\hline 0,2 & & 13 & 19 & 19 & 29 & 29 & 31 \\
\hline 0,4 & & 25 & 36 & 36 & 57 & 57 & 61 \\
\hline 0,6 & & 36 & 53 & 53 & 84 & 84 & 89 \\
\hline 0,8 & & 46 & 70 & 70 & 108 & 108 & 117 \\
\hline 1 & & 13 & 19 & 19 & 29 & 29 & 31 \\
\hline
\end{tabular}

Table 5. Specific energy consumption due to volume coefficient of global losses

It has to be noted that these are typical values, as they demand on a series of constructive details, but they demonstrate the huge energy saving potential achievable. As for the calculation purposes, the losses due to ventilation, according to the formula and the data presented in the Code, DCM Nr.38, 16/01/2003, then the following figures would result, as they are presented in Table 6.

\begin{tabular}{|l|l|l|}
\hline Climate zones A & B & C \\
\hline
\end{tabular}




\begin{tabular}{|l|l|l|l|l|l|l|l|}
\hline $\mathrm{S} / \mathrm{V} \downarrow$ & $\mathrm{DD} \rightarrow$ & 900 & 1500 & 1500 & 2500 & 2500 & 3000 \\
\hline 0,2 & 19 & 31 & 31 & 52 & 52 & 62 \\
\hline 0,4 & 19 & 31 & 31 & 52 & 52 & 62 \\
\hline 0,6 & 19 & 31 & 31 & 52 & 52 & 62 \\
\hline 0,8 & 19 & 31 & 31 & 52 & 52 & 62 \\
\hline 1 & 19 & 31 & 31 & 52 & 52 & 62 \\
\hline
\end{tabular}

Table 6. Specific energy consumption due to ventilation losses

The total specific annual energy consumption would thus result to be the one presented in Table 7. (the sum of tab. 5 and tab. 6)

\begin{tabular}{|c|c|c|c|c|c|c|c|}
\hline \multicolumn{2}{|c|}{ Climate zones } & \multicolumn{2}{|l|}{$A$} & \multicolumn{2}{|l|}{ B } & \multicolumn{2}{|l|}{ C } \\
\hline$S / V \downarrow$ & $\mathrm{DD} \rightarrow$ & 900 & 1500 & 1500 & 2500 & 2500 & 3000 \\
\hline 0,2 & & 32 & 50 & 50 & 81 & 81 & 93 \\
\hline 0,4 & & 44 & 67 & 67 & 109 & 109 & 123 \\
\hline 0,6 & & 55 & 84 & 84 & 136 & 136 & 151 \\
\hline 0,8 & & 65 & 101 & 101 & 160 & 160 & 179 \\
\hline 1 & & 76 & 117 & 117 & 186 & 186 & 205 \\
\hline
\end{tabular}

Table 7. Total specific energy consumption

The energy losses for the respective features are calculated based on the following formulas, based on the constant Degree Days method and according to Hitchin:

\section{Volume coefficient of global losses}

$$
\left.\mathrm{Q}_{\mathrm{tr}}=\mathrm{DD}^{*} \mathrm{G}_{\mathrm{vt}}{ }^{*} 24 \text { *V/(1000 * } \mathrm{S}\right) \quad\left[\mathrm{kWh} / \mathrm{m}^{2} \mathrm{a}\right]
$$

Where: $\mathrm{DD}=\quad$ Number of Degree Days

$$
\begin{array}{ll}
\text { Gvt }= & \text { as given before } \\
V= & \text { Heated volume } \\
S= & \text { Exposed surface }
\end{array}
$$

\section{Ventilation losses}

$$
Q_{\text {vent }}=D D^{*} n^{*} 24 / 1000 *{ }^{*} \mathrm{C}^{*} \mathrm{~V} /\left(3600{ }^{*} \mathrm{~S}\right) \quad\left[\mathrm{kWh} / \mathrm{m}^{2} \mathrm{a}\right]
$$

Where:

$$
\begin{array}{ll}
\mathrm{N}= & \text { Number of air changes per hour } \\
\mathrm{P}= & \text { density of air } \\
\mathrm{Cp}= & \text { specific thermal storage capacity of air } \\
\text { and hence: } &
\end{array}
$$

\section{Total losses}

$$
Q_{\text {tot }}=Q_{\text {trans }}+Q_{\text {vent }} \quad\left[\mathrm{kWh} / \mathrm{m}^{2} \mathrm{a}\right]
$$

If we compare these values, with the one that would result from the Code, DCM Nr.38, 16/01/2003, then once would have the following remarks:

If the coefficient $\mathrm{G}_{\mathrm{v} 0}$ in the full legislation text refers only to volume coefficient of global losses, then the limits set are not strict enough, and a significant reduction is achieved by the herewith proposed values, based on the reduction of volume coefficient of global losses. This difference, for each climatic zone, in terms of Degree Days (DD) for Albania.. This difference represents the energy saving potential that is exploitable. The overall consumption shown in this 
figure is based on the assumption that the ventilation losses are in both cases the same and refer to 1 air change per hour over the whole 24 hrs period.

If the $\mathrm{G}_{\mathrm{v} 0}$ coefficient proposed in the amendment, or even in the full draft, refers to volume coefficient of global losses and ventilation losses, then it leads to a very strict limit, which would incorporate for climatic zone $C$ more than $80 \mathrm{~cm}$ of insulation to achieve it. It has to be noted that even in the vast majority of building, i.e. those with $S / V$ ratios of up to 0,8 , the consumption values due to volume coefficient of global losses, according to our proposal remain below $100 \mathrm{kWh} / \mathrm{m}^{2}$ a, whilst in the more moderate cases they are between 30 and $60 \mathrm{kWh} / \mathrm{m}^{2}$. In that sense they are fully harmonized with the current European trends. The comparison of the impact of the three cases of coefficients (proposal, Code, DCM Nr.38, 16/01/2003 $G_{v 0}$ without ventilation and $G_{v 0}$ with ventilation) on the insulation needed to achieve the limits at typical buildings, is presented in the following tables.

\begin{tabular}{|c|c|c|c|c|c|c|c|}
\hline \multicolumn{2}{|c|}{ Climate zone } & \multicolumn{2}{|l|}{ A } & \multicolumn{2}{|l|}{$\mathrm{B}$} & \multicolumn{2}{|l|}{$C$} \\
\hline$S / N \downarrow$ & $\mathrm{GD} \rightarrow$ & 900 & 1500 & 1500 & 2500 & 2500 & 3000 \\
\hline 0,2 & & 3 & 5 & 5 & 6 & 6 & 9 \\
\hline 0,4 & & 3 & 5 & 5 & 6 & 6 & 9 \\
\hline 0,6 & & 4 & 5 & 5 & 6 & 6 & 9 \\
\hline 0,8 & & 4 & 5 & 5 & 7 & 7 & 10 \\
\hline 1 & & 4 & 5 & 5 & 7 & 7 & 11 \\
\hline
\end{tabular}

Table 5. Total specific energy consumption values for the three cases

\begin{tabular}{|c|c|c|c|c|c|c|c|}
\hline $\mathrm{S} / \mathrm{V}$ & $\mathrm{GD} \rightarrow$ & 900 & 1500 & 1500 & 2500 & 2500 & 3000 \\
\hline \multicolumn{8}{|l|}{0,2} \\
\hline 0,4 & & 1 & 1 & 2 & 2 & 2 & 2 \\
\hline 0,6 & & 1 & 2 & 3 & 3 & 3 & 4 \\
\hline 0,8 & & 2 & 2 & 2 & 4 & 4 & 4 \\
\hline 1 & & & & & & & \\
\hline
\end{tabular}

Proposal. Insulation thickness [cm] without ventilation

\begin{tabular}{|c|c|c|c|c|c|c|c|}
\hline$S / N \downarrow$ & $\mathrm{GD} \rightarrow$ & 900 & 1500 & 1500 & 2500 & 2500 & 3000 \\
\hline \multicolumn{8}{|l|}{0,2} \\
\hline 0,4 & & 3 & 9 & 9 & n.p. & n.p. & n.p. \\
\hline 0,6 & & 3 & 8 & 8 & 49 & 49 & n.p. \\
\hline 0,8 & & 3 & 7 & 7 & 23 & 23 & n.p. \\
\hline 1 & & & & & & & \\
\hline
\end{tabular}

Proposal. Insulation thickness [cm] with ventilation n.p. - not possible

\section{References}

[1] 2011. "A Roadmap for Moving to a Competitive Low Carbon Economy in 2050. European Commission COM (2011) 112." Report. http://eur-lex.europa.eu/LexUriServ/LexUriServ.do?uri=COM:2011:0112:FIN:EN:PD F.

[2] ACERC. 2015. "Albanian Power Rates for Business Users and Households by 1 January." http://albaniaenergy.org/acerc\%20english-2/Project\%20Platform/Interviews/albanian\%20power\%20rates.html

[3] Bürger, Veit. 2012. "Overview and Assessment of New and Innovative Integrated Policy Sets That Aim at the nZEB Standard. Report Prepared by ENTRANZE Project." www.entranze.eu/files/downloads/D5_4/Entranze_D5.4_05-2012_final.pdf.

[4] DCM 618, 2011. "National Energy Efficiency Plan of Albania 2010-2018." http://www.energycommunity.org/portal/page/portal/ENC_HOME/DOCS/1138177/NEEAP_of_the_Republic_of_Albania_20102018.pdf. 
[5] Directive 2010/31/EU of the European Parliament and of the Council of 19 May 2010 on the Energy Performance of Buildings (recast). Official Journal of the European Union, L153 of 18.06.2010. http://eurlex.europa.eu/JOHtml.do?uri=OJ:L:2010:153:SOM:EN:HTML .

[6] European Commission. 2006. Directive 2006/32/EC of the European Parliament and of the Council of 5 April 2006 on Energy End-Use Efficiency and Energy Services. The Official Journal of the European Union, L114 of 27.4.2006. http://eur-

lex.europa.eu/smartapi/cgi/sga_doc?smartapilcelexplus!prod!DocNumber\&lg=en\&type_doc=Directive\&an_doc $=2006 \&$ nu doc $=32$.

[7] European Commission. 2009. Directive 2009/125/EC of the European Parliament and of the Council of 21 October 2009 Establishing a Framework for the Setting of Ecodesign Requirements for Energy-Related Products. http://eur-lex.europa.eu/legal-content/EN/ALL/?uri=CELEX:32009L0125.

[8] European Commission. 2010a. Directive 2010/30/EU of the European Parliament and of the Council of 19 May 2010 on the Indication by Labelling and Standard Product Information of the Consumption of Energy and Other Resources by Energy-Related Products. Official Journal of the European Union, L153 of 18.06.2010. http://eur-lex.europa.eu/LexUriServ/LexUriServ.do?uri=OJ:L:2010:153:0001:01:EN:HTML

[9] European Commission. 2011. "World and European Energy and Environment Transition Outlook (WETO-T)."

[10] European Commission. 2014. "Communication from the Commission to the European Parliament, the Council, the European Economic and Social Committee and the Committee to the Regions. Energy Prices and Costs in Europe."

[11] EUROSTAT. 2015. "Energy Balances - 2013 Data (2015 Edition)." http://ec.europa.eu/eurostat/web/energy/data/energy-balances .

[12] Global petrol prices. online. "Albania LPG Prices." http://www.globalpetrolprices.com/Albania/lpg_prices/.

[13] INSTAT 2011. "CENSUS." http://www.instat.gov.al/en/figures/statistical-databases.aspx

[14] INSTAT 2012. "Albania Population and Housing Census 2011, Part 1."

[15] INSTAT 2014b. "Albanian Population Projections 2011-2031." www.instat.gov.al/.

[16] INSTAT n.d. "Statistical Databases - Construction." http://www.instat.gov.al/en/figures/statisticaldatabases.aspx .

[17] INSTAT. 2001. "CENSUS." http://www.instat.gov.al/en/census/census-2001/census-data.aspx .

[18] IPCC NGGIP. online. "Database on GHG Emision Factors (IPCC-EFDB)." http://www.ipcCnggip.iges.or.jp/EFDB/find ef main.php .

[19] Islami, Besim. 2013. "The Report on Energy Savings in Albanian Final Energy Consumption (FEC) in the Period 2010, 2011 and 2012."

[20] Kelemen, Agnes, Heather Haydock, Jozsef Feiler, Dun Craig, Guy Whiteley, and Imre Csikos. 2015. "INDC Technical Background Document Albania. (Version 25.08.2015.)."

http://www.mjedisi.gov.al/al/dokumenta/dokumenti-teknik-per-percaktimin-e-kontributit-kombetar-te-piksynuarindc-per-shqiperine .

[21] Legro, Susan, Aleksandra Novikova, and Marina Olshanskaya. 2014. "Energy Efficiency." In Sustainable Energy and Human Development in ECIS. Bratislava: United Nations Development Programme. http://www.tr.undp.org/content/dam/turkey/docs/Publications/EnvSust/UNDP,2014Sustainable\%20Energy\%20and\%20Human\%20Development\%20in\%20Europe\%20and\%20the \%20CIS.pdf .

[22] Lucon, Oswaldo, Diana Ürge-Vorsatz, Azni Zain Ahmed, Hashem Akbari, Paolo Bertoldi, Luisa F. Cabeza, Nicholas Eyre, et al. 2014. "Buildings." In Contribution of Working Group III to the Fifth Assessment Report of the Intergovernmental Panel on Climate Change. Cambridge University Press, Cambridge, United Kingdom and New York, NY, USA. http://www.ipcc.ch/report/ar5/wg3/ .

[23] Ministry of Energy and Industry 2015. Law 124/2015 "on Energy Efficiency." https://www.parlament.al/wpcontent/uploads/2015/10/ligi_nr_124_dt_12_11_2015_24797_1-1.pdf 
[24] Ministry of Energy and Industry 2016 2014b. Law 116/2016 "On Energy Performance of Buildings" https://www.parlament.al/wp-content/uploads/2016/11/ligj-nr-116-dt-10-11-2016.pdf

[25] Monstat. 2011. "CENSUS." http://www.monstat.org/eng/page.php?id=184\&pageid=184 .

[26] Republic of Albania. 2003. "The National Strategy of Energy and Plan of Action." http://www.akbn.gov.al/images/pdf/energji-te-rinovueshme/Stategjia Kombetare e Energjise.pdf .

[27] Republic of Albania. Ministry of Environment. 2014. "Implementation Plan for Transferring EU Legislation in the Field of Climate Change. Albania. Activity 4.3. of the Project Low Carbon South East Europe (SEE/D/0166/2.4/X)." Tirana. http://www.locsee.eu/plans.php .

[28] Ryding, Helene, and Andreas Seeliger. 2013. "Financing Energy Efficiency in the Balkan States. Public Financing Options for NEEAPs. 'Foot for Thought Paper'." Western Balkans Investment Framework. http://wbif.eu/uploads/lib_document/attachment/313/Neeap.pdf .

[29] Simaku 2014. "Albania Country Report. Annual Implementation Report."

[30] Simaku, Gjergji 2014. "Data Provided on the Cost of Retrofit Options."

[31] Simaku, Gjergji 2015b. "Albanian Residential Building Typology Matrix."

[32] Simaku, Gjergji 2016c. "Assessment of the Energy Performance of Buildings - Heating."

[33] Simaku, Gjergji 2016d. "Performance Calculation of Building Types."

[34] Simaku, Gjergji, Teuta Thimjo, and Thimjo Plaku. 2014a. "Albania-National Builing Typology, Energy Performance and Saving Potential. Internal SLED Report."

[35] Simaku, Gjergji. 2011. "Norms, Regulations, Design and Construction Conditions, for Heat Generation and Energy Saving in Dwellings and Public Buildings."

[36] Singh, Jas, Dilip Limaye, and Kathrin Hofer. 2014. "Western Balkans: Scaling up Energy Efficiency in Buildings." World Bank Group. http://documents.worldbank.org/curated/en/2014/06/19782698/westernbalkans-scaling-up-energy-efficiency-buildings-final-report .

[37] Szabo, Laszlo, Andras Mezosi, Zsuzsanna Pato, and Slobodan Markovic. 2015. "Support for Low-Emission Development in South Eastern Europe (SLED). Electricity Sector Modelling Assessment in Montenegro."

[38] Ürge-Vorsatz, Diana, Nick Eyre, Peter Graham, Danny L. D. Harvey, E. Hertwich, Yi Jiang, Eberhard Jochem, et al. 2012. "Energy End-Use (Efficiency): Buildings." In . International Institute for Applied Systems Analysis (IIASA).

[39] Weibull, W. 1951. "A Statistical Distribution Function of Wide Applicability." J. Appl. Mech.- Trans. ASME 18 (3): 293-97.

[40] Welch, Cory, and Rogers Rogers. 2010. "Estimating the Remaining Useful Life of Residential Appliances." In 2010 ACEEE Summer Study

[41] World Bank 2015. "World Bank Commodities Price Forecast (nominal US Dollars), Released: July 20, 2015." http://econ.worldbank.org/WBSITE/EXTERNAL/EXTDEC/EXTDECPROSPECTS/0, contentMDK:21574907 m enuPK:7859231 pagePK:64165401 piPK:64165026 theSitePK:476883,00.html .

[42] World Bank. online. "Database." http://data.worldbank.org/. 